\title{
HR Analytics at Work: Making More Powered Organisations
}

Effulgence

Vol. 16 No. 1 (Special Issue 2)

January - June, 2018 Rukmini Devi Institute of Advanced Studies

E-mail : effulgence@rdias.ac.in, Website : www.rdias.ac.in

http://effulgence.rdias.ac.in/user/default.aspx

https://dx.doi.org/10.33601/effulgence.rdias/v16/iSpl2/2018/132-141

\section{Ms. Parul Manchanda ${ }^{1}$ \\ Shruti Gulati ${ }^{2}$}

\begin{abstract}
Purpose - Today, the aim of the organizations and their leaders is not merely efficiency but it is something beyond. The experts in charge of the varied departments like marketing, finance, supply chain management, information technology and customer relationship management have been recognising the fact, howimperative the data driven insights are to generate notable business results. However, the human resource departments have always had a hard time while connecting the data to better business performance. While the HR often focuses principally on its own performance, the need of an hour is to shift this focus to the level of talent decision it supports.
\end{abstract}

The motive of this paper is to study the significance of Human Resource Analytics in managing the human resource of the organizations and also to know its effect on the outcomes of their businesses. It would also emphasize on the evolution of HR Analytics from HR Metrics and various fundamental factors which when combined with recent and ever-rising interest in evidence-based management, have led to the emergence of Workforce Analytics. Furthermore, it would throw some light on the increasingly growing interest of various companies in HR Analytics and the different tools employed by them to reduce attrition rate, mitigate risks and build a value added training culture in the organizations too.

Design/ Approach/ Methodology - Existing research was examined to draw linkages between the traditional and fundamental tools used for measuring the performance of the people at work and predictive action taken by making use of workforce analytical tools for generating better business outcomes. The existing gaps in HR metrics, which led to HR Analytics, were also disclosed.

Findings - The literature that has been studied suggests that there is a positive influence of using HR Analytics at workplace. However, the concept is still not in practice by all the business organizations for the human resource has not been very adaptive to analytics.

Research Limitations/Implications - Although the question of measuring employee performance is of great concern and can pose a major threat on the business results if not measured properly, yet the analytics has not been appreciated in the organizations to a greatextent.

1. Research Scholar, USMS (GGSIPU), manchanda91@gmail.com

2. Student, Institute of Information Technology and Management 
Originality/Value - This paper studies the question of the effect of measurement of employee performance on the business outcomes. It illustrates the HR analytics practices which have been in practice by the various organizations like Google, A.C. Milan, Sysco, Valero and Convergys to be included in the culture of organizations world-wide so as to make better strategic decisions on the people side of the business.

Keywords: HR Analytics, Human Resource Analytics, Workforce Analytics, HR Metrics, Scorecard, Predictive Modelling, Employee Engagement.

\section{INTRODUCTION to HR Analytics}

s per the research of major databases, Human
Resource Analytics (HRA), known to be first used in the HR published literature in 2003-04, is a relatively new term. IT enabled human resource practice takes help of visual, descriptive, and statistical analyses of the data procured from human capital, HR processes, organizational performances, and external-oriented economic benchmarks in order to enable data-driven decision making thereby creating a fruitful impact on business. HR analytics can be defined as an analytics used in constructing a storyline from the data procured. It is related to processing of raw data needed to solve the troubled HR metrics and also highlighting the critical areas to work upon in order to help the top management make important strategic decisions for the organization. The term does not mean the same to every person. To some, it is only a process for systematic reporting on an array of HR metrics compensation (e.g., comparison of compensation to the broader market through benchmarking), time to hire, turnover, employee engagement. On the other hand, others have equated it with the organizational performance, despite being known that people factors can directly be linked to business outcomes today. Thus, the HR Analytics Project is by far the largest study on the topic of HR Research and Analytics with respect to the application of the concept by various global firms and the benefit derived there forth. However, employee engagement, in a wider sense requires an intense scrutiny by HR professionals to become favourable practitioners of HR Analytics (Bassi and McMurrer, 2010). HR analytics promises two things: 1) to raise the level of HR profession, 2) to serve as a source of competitive advantage to the organizations which are putting the concept into practice. This promise, in turn, requires an individual and organization as a whole to gain clarity over certain issues in HR analytics and excel the art and science of HR analytics.

\section{Evolution of HR Analytics}

As primary task of an HR has emerged from that of 'personnel control' to 'people developer' followed by 'talent multiplier', the concept of HR and its investments have gained importance in terms of how well the latter improves the bottom line (Cheese et al., 2007). Systematic work and investment has been made in developing measures for capturing the effectiveness and efficiency of employees since the days of scientific management (Taylor, 1911) namely, the fatigue study that came into existence. Similar to this was the industrial and organizational psychology (Munsterberg, 1913) that proved to be a good measurement tool. Development of several methods of quantitative analysis that took place along with its growing use in decision making during and post the great World War II, have significantly proved to be a contributing factor in $\mathrm{HR}$ analytics. In fact, most of the common HR metrics that are in existence today were considered and developed initially during this period (e.g., Hawk, 1967). Thus, it can be seen that the interest of HR metrics and analytics is not new to the people at work. In addition to this, the quality revolution that took place in 1980s and 1990s, including Six Sigma, Total Quality Management (TQM), and lean manufacturing, contributed significantly in arousing expectations of the managers about the availability of the organizational data thereby increasing the 
capability of using the same data to generate analytics for supporting managerial decisions. Introduction of balanced scorecard by Kaplan and Norton's (1996) further helped in refining managers' thinking about metrics.All such factors in combination with the ever growing interest in strategic and evidence-based management have generated a rapidly growing interest in Workforce metrics and analytics. Most of the companies today are performing HR metrics based on employee counts (e.g., turnover ratio, average tenure etc) while a few others are moving towards HR analytics for effective business outcomes. There is a wide difference between the two terms.HR metrics are the measures of key HRM outcomes, classified as efficiency, effectiveness or impact (Lawler, Levenson and Boudreau, 2004). In contrast, Lawler et al. (2004) states that HR Analytics are not measures but rather represent statistical techniques and experimental approaches that can be used to show the impact of HR activities. This implies that HR metrics is not same as HR analytics. The latter however, is an extension to the former involving more revolutionary analysis of the data related to HR. The collected data with HR metrics is usually the ending point. The data gathered is nothing but a mere count of the workforce. Human capital management takes place with the help of workforce analytics. The collected data being the ending point for HR metrics becomes the starting point for workforce analytics. The application of intelligence and experience to the data for further interpretation and use makes it a more strategic and proactive aspect than plug-in metrics. Also, it enables a 360-degree view of human capital investment for it involves internal and external data integration in order to giving a deeper insight than metrics.

\section{Research Methodology}

A thorough and wide exploratory search of existing literature was directed on an assortment of online databases to deliver an inclusive list of journal articles. After which the companies practising, HR Analytics were identifies, and have been presented in the following paper. Google Scholar was also traversed to select studies that comprised any of the underneath stated key terms. The online databases used were, Emerald Management, Taylor and Francis, and articles have been referred to. The key words used for reaching out the included articles for this paper from among the various journals are: "HR Analytics, Human Resource Analytics, Workforce Analytics, HR Metrics, Scorecard, Predictive Modelling, and Employee Engagement. This research paper would be of keen interest to practitioners, academicians and scholars, eager to learn and apply the various HR Analytic techniques into practice.

\section{Elucidating on HR Analytics and its Diverse Tools}

\section{HR Analytics}

- HR Analytics is an evidence-based approach for making better decisions on the people side of the business; it consists of an array of tools and technologies, ranging from simple reporting of HR metrics all the way up to predictive modelling' (Bassi, 2011, p. 16).

Bassi (2011) states that HR Analytics can be referred both as 'systematic reporting of an array of HR metrics' or more intensive and revolutionary solutions, based on 'predictive models' and 'what-if scenarios'. In addition, his definition includes the notion of an 'evidencebased approach' used in making decisions on the 'people side of the businesses'.

- Finally focusing on the link with strategic HRM, Mondare, Douthitt, and Carson (2011) define HR Analytics as demonstrating the direct impact of people on important business outcomes. It helps identify the skills of the employees and create the leaders of tomorrow.

- Business analytics is defined as an "extensive use of data, statistical and quantitative analysis, explanatory and predictive models and factbased management to drive decisions and actions" (Davenport 2007). 


\section{Tools for HR Analytics}

- Predictive Modelling: For some people, activities/ processes constituting HR analytics are the ones that involve 'high-end' predictive modelling. Predictive Modelling basically refers to the 'what-if' scenarios which forecast the impact of changing policies or conditions. It answers the questions as to why employees choose to be in a company and are not likely to leave. It is easy to determine the most important values of the employees with the help of analytics. The data once collected can further be used to create a model to boost the retention rates. Thus, the application of analytics gives way to predictive action which helps the companies anticipate future behaviours and preferences of the employees and also enable them to hold on to their valuable talent through tailor-made HR practices. The ultimate goal of almost all the analytics efforts made is Predictive Analysis. Under this, attempts are made to develop such organizational system models which can predict future outcomes and also to understand the impact of hypothetical changes in organizations. For example, if existing system of an organization goes through a specific change and eventually originates a correlation prevailing between employees' satisfaction from their job and their respective turnover, the HR department can utilize this data to depict the changes essential to the work situation of its workforce. Efforts made to initiate the use of balanced scorecards are referred to as elementary predictive system. Results generated through further analysis by using scorecards, quantitative modeling etc, help the HR management know the eligible person for the succeeding position. Engagement in such efforts can therefore, lead to enhancement in models' quality underlying predictive analyses. To conclude, the HR analytics constituting predictive action becomes the key element for succession and strategic planning i.e., providing for replacement and retention of talents within the organization.
- HR Scorecards and Dashboards: An HR scorecard/ dashboardis a reporting tool which helps in ad-hoc querying, drilling-down, and reporting of $\mathrm{HR}$ metrics and indicators.It is amongst one of the most frequent analytics elements used today. The balanced scorecard helps the organization overcome its limitation of major reliance on financial indicators of performance. Such measures are able to focus only on what has already happened instead of providing information about what will happen. Balanced scorecards have an edge over all such measures. For example, it can be used to give specific colours (as per the criteria) to the task/people depending upon their performances in the organization. This way an organization can direct its focus on to performing employees as it provides an ease in detecting the nonperforming employees. This is just one way to make use of the HR scorecards. However, it can be used for developing leading indicators of performance from diverse perspectives, including customer satisfaction, process effectiveness (e.g., cost of hiring), employee development and financial performance.

- Talent Supply Chain: The working of talent supply chain starts with projecting the future talent needs in the organizations by analyzing the data relating to past experience and already planned capital projects (Sullivan and Burnett, 2006). It is followed by communicating the talent needs of the organization to the best sources to procure talents from, in accordance with supplier's record of efficiency (time and cost of hire) and effectiveness (reliability and level of quality of hire). Lastly, optimization of decisions takes place using real-time, system-wide performance data of all such talent procurement sources for creating the most appropriate supply chain. Talent supply chain approach if used effectively in the organization can increase the precision of activities related to workforce planning.

- LAMP Model: LAMP stands for Logic, Analytics, Measures, and Processes, the four 
critical components of a measurement system required to discover the evidence-based relationships as well as to persuade enhanced decisions based on the analyses. The elements of this model also help understand the cause and effect relationship between human resource management processes and outcomes of the business (Boudreau and Ramstad, 2007).

It has been observed that the progression of information technology (IT) and its extensiveness is the reality of the current times. People in the IT connected world often leave a trail of data. Organisations have realised a fact that, they can use the data to their advantage with the presence of the ever evolving and sophisticated technology. Thus, this particular sentiment has witnessed the rise of analytics being applied in the various organisations. This research paper intends to study organisations such as Google, Sysco, A.C. Milan, Valero, Convergys and a lot more, which have been successful in gaining competitive advantage by putting the concept of HR analytics into practice. They have known to be the early adopters of the concept.

\section{- Google}

Google, an American multinational technology company specializing in internet-related products and services, is well known for its tough screening process of new job applicants. With the rapid growth of the multinational company, it has become an acute problem to find the right people for the right job. Initially, the company doubted if it was able to identify the best candidates using traditional techniques such as grade point average for screening the attractive candidates. It eventually realized that a more effective way was required for managing the task of identifying the successful would-be employees. It thus started with a strategic approach of collecting a comprehensive database from the current employees on the basis of their attitudes, personality, behaviours, job performance and biographical information as well as the same information from applicants and thereby matching the above data collected from both the sources. The task involves further application of an algorithm to calculate a score helpful to predict the chances of candidates being succeeded at the job (Hansell, 2007). Google is capable of managing its increasingly growing workforce population with the help of this analytical approach. The approach also ensures that the potential employees who might have made it through the previous processes are not overlooked by the company. Google uses a term called 'People Analytics' to describe its data driven approach to human resource management. People analytics approach stated its underlying basic assumption that the most effective and influential decisions that a firm could make would be decisions related to accurate and error free people management. It can best manage the employee attrition problem through quantitative analysis. For example, quantitative analysis on number of people signing up for retirement program can act as a better predictor of employees who are going to leave the organization after a relatively short period of time. Table 1 shows a list of tools used by Google for performing HR Analytics, their purpose, operations, and the benefits derived from using them in the organization. 
Table1. HR Analytical Tools, Purpose, Operations \& Benefits Derived

\begin{tabular}{|c|c|c|c|c|}
\hline S. No. & $\begin{array}{l}\text { Tools used for HR } \\
\text { Analytics }\end{array}$ & Purpose of Tool & Operation of Tool & Benefits Derived \\
\hline 1 & Project Oxygen & $\begin{array}{l}\text { To identify the attributes } \\
\text { of good managers and } \\
\text { great leaders }\end{array}$ & $\begin{array}{l}\text { Internal data analysis, } \\
\text { identification of } \\
\text { characteristics, } \\
\text { frequent feedback, } \\
\text { rating of managers by } \\
\text { employees twice a } \\
\text { year }\end{array}$ & $\begin{array}{l}\text { Improvement in } \\
\text { managers' } \\
\text { performance, } \\
\text { successful leaders }\end{array}$ \\
\hline 2 & PiLab by Google & $\begin{array}{l}\text { To establish the most } \\
\text { productive approaches for } \\
\text { managing workforce and } \\
\text { maintaining a high- } \\
\text { yielding environment }\end{array}$ & $\begin{array}{l}\text { Scientific data testing } \\
\text { and experimentation - } \\
\text { e.g., reduction of the } \\
\text { plate size in the } \\
\text { cafeteria can reduce } \\
\text { the employee's calorie } \\
\text { intake\& improve } \\
\text { health }\end{array}$ & $\begin{array}{l}\text { Most deserving } \\
\text { rewards } \\
\text { employees, } \\
\text { improvement in } \\
\text { health }\end{array}$ \\
\hline 3 & Retention Algorithm & $\begin{array}{l}\text { To proactively forecast the } \\
\text { possibility of employees } \\
\text { who can become a } \\
\text { retention problem in the } \\
\text { near future }\end{array}$ & $\begin{array}{l}\text { Mathematical } \\
\text { algorithm involving } \\
\text { quantitative analysis }\end{array}$ & $\begin{array}{lr}\text { Reduced } & \text { employee } \\
\text { attrition, } & \text { provides } \\
\text { retention } & \text { solutions } \\
\text { beforehand } & \end{array}$ \\
\hline 4 & Predictive Modelling & $\begin{array}{lr}\text { To improve the forecasts } \\
\text { related to upcoming } \\
\text { opportunities r and } \\
\text { problems of managing } \\
\text { people at work }\end{array}$ & $\begin{array}{l}\text { Use of 'what-if' } \\
\text { analysis and } \\
\begin{array}{l}\text { development } \\
\text { predictive models }\end{array}\end{array}$ & $\begin{array}{l}\text { More effective and } \\
\text { strategic workforce } \\
\text { planning, better } \\
\text { future outcomes }\end{array}$ \\
\hline 5 & Improving Diversity & $\begin{array}{l}\text { To solve diversity related } \\
\text { problems at workplace }\end{array}$ & 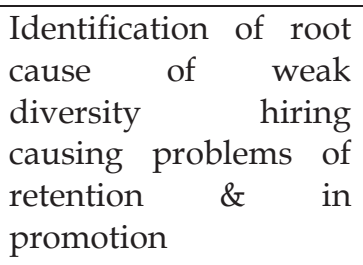 & $\begin{array}{l}\text { Better results at } \\
\text { recruitment, retention } \\
\text { and promotion }\end{array}$ \\
\hline 6 & $\begin{array}{lr}\text { Effective } & \text { Hiring } \\
\text { Algorithm } & \text { under } \\
\text { 'Project Janus' } & \end{array}$ & $\begin{array}{l}\text { To predict the candidates } \\
\text { with highestpossibility of } \\
\text { succeeding at the } \\
\text { workplace once being } \\
\text { hired }\end{array}$ & $\begin{array}{l}\text { Matching the data of } \\
\text { individual job seekers } \\
\text { with current } \\
\text { employees' } \\
\text { comprehensive } \\
\text { database by applying } \\
\text { strategic approach in } \\
\text { hiring process (e.g., } \\
\text { hiring decision made } \\
\text { by group of managers) }\end{array}$ & $\begin{array}{l}\text { Prevention of hiring } \\
\text { people for short-term } \\
\text { by individual hiring } \\
\text { managers as per their } \\
\text { needs, prevention of } \\
\text { top candidates from } \\
\text { getting rejected, } \\
\text { identification of } \\
\text { would-be successful } \\
\text { employees }\end{array}$ \\
\hline
\end{tabular}




\begin{tabular}{|l|l|l|l|l|l|}
\hline 7 & $\begin{array}{l}\text { Calculation of the } \\
\text { value of } \\
\text { performers }\end{array}$ & $\begin{array}{l}\text { To provide necessary } \\
\text { resources for hiring, } \\
\text { retaining and developing } \\
\text { outstanding talent }\end{array}$ & $\begin{array}{l}\text { Calculation } \\
\text { variation } \\
\text { performances of an an } \\
\text { extraordinary and } \\
\text { average technologist }\end{array}$ & $\begin{array}{l}\text { Exceptional support } \\
\text { from executives }\end{array}$ \\
\hline 8 & $\begin{array}{l}\text { Workplace Design } \\
\text { Drives }\end{array}$ & $\begin{array}{l}\text { To increase cooperation } \\
\text { between employees from } \\
\text { different functions, fun } \\
\text { and learning at workplace }\end{array}$ & $\begin{array}{l}\text { Conscious design of } \\
\text { workplace (e.g., a } \\
\text { track on the time spent } \\
\text { by employees in cafe) }\end{array}$ & $\begin{array}{l}\text { Attraction, retention } \\
\text { and cooperation of } \\
\text { employees, increased } \\
\text { innovation }\end{array}$ \\
\hline
\end{tabular}

[Source: Author's own work]

\section{- Sysco}

Sysco Corporation, a global food-service marketer and distributor's key to success is the strong connection and constant contact between its delivery people and its customers. Its customers include hospitals, nursing homes, restaurants, hotels, schools, colleges, sports parks, and summer camps etc where it is essential to provide meals. It is thus crucial for the company to retain its skilled and satisfied employees for delivery function in order to ensure good business results. It uses three metrics at the forefront namely, work climate and employee satisfaction, productivity (to be measured in terms of employees per 100,000 cases of food sold) and retention of workforce in the organisation. With several years of measuring and analyzing the key metrics, it could effectively link its talent management practices to business results (Cascio, 2005). Furthermore, in order to bring the high levels of employment satisfaction among the employees, the company identifies its under-performing units based on seven dimensions that are established to measure its work environment: effectiveness of front-line supervisors, quality of life, employee engagement, rewards for performance, diversity, leadership support of employees and customer focus. Improvements in employee satisfaction enhance customer satisfaction and loyalty which in turn bring larger revenues and reduction in costs due to low levels of employee turnover. Within six years, Sysco could improve its retention rate for delivery associates from 65 percent to 85 percent. Also, it could save $\$ 50$ million in the hiring and training process (Cascio, 2006).

\section{- Valero}

Valero Energy Corporation, texas-based oil refinery, had 2000 employees and revenues of \$118 million in 2000 when recruiting operations of the company were entirely paper-based. In 2002, it started building a world-class staffing capability to meet the rapidly growing talent needs. After six years, its revenues rose to \$75billion with 22000 employees through analytical transformation of talent sourcing (Frauenheim, 2006). The company created supply chains for its human capital requirement. The company's talent supply chain approach proved to be successful when it could improve the workforce planning activities. Moreover, for the first time it became possible to develop pipelines of talent in order to meet the future demand for specific talent needs in the upcoming years (Schneider, 2006).

\section{- AC Milan}

A.C. Milan, an Italian soccer team, like all professional sports teams, is prone to the loss of its key players due to injury. Even after spending millions of euros to acquire superstar Fernando Redondo, the team could not prevent him from getting injured resulting which the management realised that durability of the players was also important in addition to possessing a talent for the game. Thus, it came up with its own lab to know the soccer players from inside out. The lab gathers data points and tests the physical as well as psychological elements of the players that might lead to injury. Such extensive analysis of the data helped the team decide the well-equipped players who are likely to be performing at high levels and also the ones who are likely to suffer injuries. A system is developed 
with the help of predictive algorithms to describe the appropriate rest period required by each player giving a deeper understanding to Taylor's fatigue study (Kuper, 2008). Accordingly, training regimens were customized for maximizing players' longevity. This analytical approach to managing talent paid off for the team by reducing the injuries by over 90 percent and sustaining their ability to perform well.

\section{- Convergys}

Convergys is known to sell customer management and information management products to businesses in 40 countries. It started a consumer marketing technique known as conjoint analysis in order to maintain a level of staffing and to reduce employee attrition. The analysis helps the company in two ways; when used with products, it determines how different combinations of features are valued by people whereas when used with employees, it figures out the benefits that have likelihood of encouraging people to stay in the organization. Using this tool, it recognized that if employees were paid half of their annual pay rise twice a year instead of the whole amount once a year, they were more likely to continue with the organization thereby reducing the overall cost of hiring and training fresh talent. Besides this, the company chose to offer varied benefits customized according to different locations. This led to establishment of Employee Engagement Teams at each centre to facilitate flexible scheduling, employee recognition as per the location demands. It could save $\$ 57$ million that would have been spent for hiring purposes and also reduce retention by 58,000 employees.

\section{- JetBlue}

JetBlue Airways Corporation, the sixth largest airline in the United States, introduced a model called 'Crewmember Net Promoter Score' to know the consequences of change in compensation of employees and to determine the executive bonuses. This model helps the company carefully examine the engagement of employees every month when each one of them is specifically asked for his suggestions and recommendations on his hiring date once a year. Besides this, the company is open and transparent to its end users (i.e., employees and managers) regarding the process of data collection, reason of collecting such data, and formulae used etc. Similar to this are the companies such as Best Buy, AT\&T, RBS, Intel, Dell, Proctor \& Gamble which have achieved strategic benefits by putting HR analytics into practice.

Table 2 shows a list of companies and the various tools they use for performing HR Analytics.

Table2. Companies and their Various Tools for HR Analytics

\begin{tabular}{|c|c|c|c|c|}
\hline S.No. & Companies & Tools & Purpose & Outcome \\
\hline 1 & Sysco & $\begin{array}{l}\text { HR Analytics - } \\
\text { measuring dimensions } \\
\text { of work environment, } \\
\text { identifying under- } \\
\text { performing units }\end{array}$ & $\begin{array}{l}\text { To establish causal links } \\
\text { between work climate } \\
\text { surveys, delivery driver } \\
\text { employee satisfaction, } \\
\text { customer loyalty and } \\
\text { higher revenue }\end{array}$ & $\begin{array}{lr}\text { Increased revenue, } \\
\text { improvement in } \\
\text { retention rate, } \\
\text { employee } & \\
\text { satisfaction } & \end{array}$ \\
\hline 2 & Valero & $\begin{array}{lrr}\begin{array}{l}\text { Creation of } \\
\text { Supply }\end{array} & \begin{array}{r}\text { Talent } \\
\text { Chain, }\end{array} \\
\text { Scorecards } & & \text { and } \\
\text { Dashboards } & & \end{array}$ & $\begin{array}{l}\text { To examine the } \\
\text { performance of supplier } \\
\text { of talent by analyzing } \\
\text { the data collected on } \\
\text { quality of talent }\end{array}$ & $\begin{array}{l}\text { Forecast specific } \\
\text { talent needs }\end{array}$ \\
\hline
\end{tabular}




\begin{tabular}{|c|c|c|c|c|}
\hline 3 & A.C. Milan & $\begin{array}{l}\text { Research lab and } \\
\text { predictive algorithms }\end{array}$ & $\begin{array}{l}\text { To sustain the ability of } \\
\text { players to perform in } \\
\text { matches }\end{array}$ & $\begin{array}{l}\text { Increased number of } \\
\text { healthy employees } \\
\text { and their durability, } \\
\text { prevent injury }\end{array}$ \\
\hline 4 & Convergys & Conjoint Analysis & $\begin{array}{l}\text { To figure out the } \\
\text { benefits likely to } \\
\text { encourage employees to } \\
\text { stay }\end{array}$ & $\begin{array}{l}\text { Reduction in } \\
\text { attrition } \\
\text { employees and costs } \\
\text { of hiring and } \\
\text { recruitment }\end{array}$ \\
\hline 5 & JetBlue & $\begin{array}{ll}\text { Crewmember } & \text { Net } \\
\text { Promoter Score } & \end{array}$ & $\begin{array}{l}\text { To study the impact of } \\
\text { changes taking place in } \\
\text { employee remuneration } \\
\text { and to help ascertain } \\
\text { executive bonuses }\end{array}$ & $\begin{array}{l}\text { Effective employee } \\
\text { engagement }\end{array}$ \\
\hline
\end{tabular}

[Source: Author's own work]

\section{CONCLUSION}

In spite of being such a hot topic in today's scenario, HR analytics has not been appreciated by management community largely unlike the other HR issues including employee turnover, goal setting, and performance-based rewards. Little do they know that it can pave the way for resolving all such issues. Having said that, quite a few companies can be seen to be the early-adopters of a broad range of HR research and analytics practices which extend beyond simple metrics and even scorecards. Those seeking to use human capital analytics to gain competitive advantage follow a systematic progression from reporting to analytics. The process also involves predictive analysis of what might/ should happen. They have begun to look beyond historical data which used to be a by-product of transaction and compliance reporting systems. There is a major shift in their focus so as to exploit the prevailing opportunities in the market and to see the threats well before they encounter them. Human capital analytics enable the organizations to direct their resources towards people and programs essential for high levels of performance.The profession has a long way to go in order to play an influential role in development of human resource strategy and decision making. However, companies require right set of employees with appropriate knowledge and skills for collecting the accurate data, performing right statistical analyses and communicating the meaningful results in an accessible way. In addition to this, there must be a constant support from stakeholders. The companies may be looking forward to using e-HRM software systems to ensure IT enabled HR analytics.

\section{REFERENCES}

1) Bassi, L. (2011). Raging debates in HR analytics. People and Strategy, 34(2), 14.

2) Bassi, L., \&McMurrer, D. (2010). Does Engagement Really Drive Results?. Talent Management Magazine, 42-48.

3) Boudreau, J. W., \& Ramstad, P. M. (2007). Beyond HR: The new science of human capital. Harvard Business Press.

4) Cascio, W. F. (2006). The economic impact of employee behaviors on organizational performance. In America at Work (pp. 241-256). Palgrave Macmillan, New York.

5) Cheese, P., Thomas, R.J. and Craig, E. (2007), The talent powered organization: Strategies for globalization, talent management and high performance. Kogan Page Publishers.

6) Davenport, T. H., \& Harris, J. G. (2007). Competing on analytics: The new science of 
winning. Harvard Business Press.

7) Frauenheim, E. (2006). Valero Energy: Optimas Award Winner for Innovation. Workforce Management, March, 13.

8) Globalization, Talent Management and High Performance, Kogan Page, London.

9) Hansell, S. (2007). Google answer to filling jobs is an algorithm. New York Times, 3.

10) Hawk, R. H. (1967). The recruitment function. American Management Association.

11) Kaplan, R. S., \& Norton, D. P. (1996). The balanced scorecard: translating strategy into action. Harvard Business Press.

12) Kuper, S. (2008). Milan Lab's secret of youth. Financial Times, February, 29.

13) Lawler III, E. E., Levenson, A. R., \& Boudreau, J. W. (2004). HR metrics and analytics: Use and impact. People and Strategy, 27(4), 27.

14) Mondore, S., Douthitt, S., \& Carson, M. (2011). Maximizing the impact and effectiveness of HR analytics to drive business outcomes. People and Strategy, 34(2), 20.

15) Mullich, J. (2005). Attacking Attrition at Convergys. Workforce Management, March.

16) Munsterberg, H. (1998). Psychology and industrial efficiency (Vol. 49). A\&C Black.

17) Schneider, C. (2006). The new human-capital metrics. CFO Magazine, February, 15.

18) Sullivan, J. (2013). How Google is using people analytics to completely reinvent HR. TLNT: The Business of HR, 26.

19) Sullivan, J. and Burnett, M. (2006), Six Best Practices in Recruiting, March 19.

20) Taylor, F. (1911). The principles of scientific management. London: Harper Brothers. 